\title{
LITTERFALL PRODUCTION AS A FUNCTION OF PLANTING SEEDLINGS SYSTEM IN A TWO YEARS FOREST RESTORATION AREA IN THE COASTAL- PLAIN OF CARAGUATATUBA, SÃO PAULO, BRAZIL ${ }^{1}$
}

\author{
Leda Lorenzo ${ }^{2}$, Virgínia Hamer Campagnaro ${ }^{2 *}$
}

\begin{abstract}
${ }^{1}$ Received on 13.03.2017 accepted for publication on 07.06.2017.
${ }^{2}$ Universidade de São Paulo,Departamento de Ciências Ambientais,Diadema, São Paulo, Brasil. E-mail: <ledalomo@gmail.com> and $<$ vhcampagnaro@hotmail.com>.

*Corresponding author.
\end{abstract}

\begin{abstract}
Seedlings plantation combining pioneer and non-pioneer species facilitates the restoration of ecological processes, such as litterfall production. Litterfall is fundamental to reestablish nutrient cycling and to recover soil fertility in early stages of restoration. This study evaluated litterfall production in a two-year forest restoration area (transitional rain forest: Restinga high forest - submontane rain forest) by comparing differences in litter production between seedlings plantation in rows (LI, $2 \times 2 \mathrm{~m}$ spacing) and in clusters (NU, $30 \times 30 \mathrm{~cm}$ spacing). Litterfall was collected monthly during 24 months in 62 plots (27 LI; $27 \mathrm{NU}$ and 8 controls without plantation). Litterfall dry mass, litter fractions (leaves, twigs, reproductive and miscellaneous), dry mass from seedling material and dry mass from vegetation prior to the restoration were determined. Annual litter production was higher in restored plots $\left(254.91 \mathrm{~g} . \mathrm{m}^{-2}\right)$ than in control ones $\left(120.99 \mathrm{~g} . \mathrm{m}^{-2}\right)$ and there was no difference between rows $\left(259.39 \mathrm{~g} \cdot \mathrm{m}^{-2}\right)$ and clusters $\left(250.59 \mathrm{~g} \cdot \mathrm{m}^{-2}\right)$. There was substitution of the litter type with time, which was higher in restored than in control plots, but there was no difference between rows and clusters. Results indicated that: (1) planting seedlings facilitates litterfall recovery; (2) there is litter substitution as from the beginning of the restoration; and (3) planting seedlings in rows or clusters is equally efficient to restore litter production. In conclusion, planting seedlings leads to higher litter production and it could benefit the recovery of nutrients cycling in degraded areas, regardless of the disposition of seedlings in rows or clusters. Keywords: Litter; Clusters; Planting density.
\end{abstract}

\section{PRODUÇÃO DE SERAPILHEIRA EM FUNÇÃO DO SISTEMA DE PLANTIO DE MUDAS EM ÁREA DE RESTAURAÇÃO FLORESTAL DE DOIS ANOS NA PLANÍCIE COSTEIRA DE CARAGUATATUBA, SÃO PAULO, BRASIL}

\begin{abstract}
RESUMO - O plantio de mudas combinando espécies pioneiras e não pioneiras facilita a restauração de processos ecológicos, como a produção de serapilheira. A serapilheira é fundamental para restabelecer a ciclagem de nutrientes e recuperar a fertilidade do solo em estágios iniciais de restauração. Este estudo avaliou a produção de serapilheira em um reflorestamento (floresta de transição: restinga alta - floresta de encosta submontana) e testou diferenças entre sistemas de plantio de mudas em linhas (LI, espaçamento $2 \times 2 \mathrm{~m}$ ) e em grupos adensados ( $N U$, espaçamento $30 \times 30 \mathrm{~cm}$ ). A serapilheira produzida foi coletada mensalmente durante 24 meses em 62 parcelas (27 LI; 27 NU e 8 controles sem plantio). Foram determinados: o peso seco da serapilheira, das suas frações (folhas, galhos, reprodutivo e detritos) e separada a serapilheira produzida pelas mudas e pela vegetação anterior ao reflorestamento. A produção anual foi maior nos plantios (254,91 g. $\left.\mathrm{m}^{-2}\right)$ do que nos controles $\left(120,99 \mathrm{~g} . \mathrm{m}^{-2}\right)$, não houve diferenças entre LI $\left(259,39 \mathrm{~g} . \mathrm{m}^{-2}\right)$ e NU $\left(250,59 \mathrm{~g} . \mathrm{m}^{-}\right.$ $\left.{ }^{2}\right)$. Houve substituição da serapilheira ao longo do tempo, maior nos plantios do que nos controles, mas sem diferenças entre sistemas de plantio. Os resultados indicaram que: (1) o plantio de mudas facilitou a recuperação da produção de serapilheira, (2) houve substituição do material produzido já em fases iniciais da restauração e (3) o plantio de mudas em linhas ou agrupadas foi igualmente eficiente. Conclui-se que o plantio de mudas aumenta a produção de serapilheira e pode favorecer a recuperação da ciclagem de nutrientes em áreas degradadas, independentemente de sua disposição em linhas ou grupos adensados.
\end{abstract}

Palavras-Chave: Liteira; Mudas agrupadas; Densidade de plantio. 


\section{INTRODUCTION}

Over the last 50 years humans have changed ecosystems more quickly and with most extension than any other period of human history, resulting in reductions of biodiversity, water quantity and quality and other ecosystems services which are essential for human well-being (Millennium Ecosystem Assessment, 2005). Brazilian coast ecosystems had been intensely changed in the last decades; vegetation had been quickly degraded due to growing urbanization, establishment of exotic species, changes of the original substrate and selective collection of ornamental plant species (Rocha et al., 2007). This degradation leads to the need of restoring degraded areas in order to reestablishment ecosystem services.

Planting seedlings is one of the most used techniques to restore forests (Ruiz-Jaen and Aide, 2005). Over the last years, the planting of seedlings has combined pioneer and non-pioneer species. The planting of seedlings can be done in rows or in clusters of grouped seedlings, which has been proposed as a tool to faster recover ecological processes (Rodrigues et al., 2009). The combination of pioneers and non-pioneers makes the restoration faster and facilitates the management as the accelerated growth of the pioneer species leads to the formation of shadow, creating proper conditions (less direct solar radiation and higher moisture) for the development of the non-pioneer species. Besides, the shadow caused by the pioneer species inhibits the growing of grasses, once these plants need direct solar radiation to grow and/or germinate (Rodrigues et al., 2009).

The monitoring of the restoration areas is fundamental to verify the success of the restoration and to guarantee the maintainance of restored ecosystems over time, which is attained through the recovery of its ecological processes. One of the ecological processes that can be used as bioindicator for monitoring restoration areas is the litterfall production (Machado et al., 2008; Londe et al., 2016).

The litter is the layer formed by the deposit of organic materials on the soil. The presence of litter is benefic to soil as it reduces erosion rates (by damping the impact of rain) and temperature oscillations on soil surface (Mateus et al., 2013). Furthermore, it is important for the structuring of plant community once it has seeds and it increases the retention of available water for plants (Miranda Neto et al., 2014). The presence of litter can promote the emergence of seedlings and therefore, the ecosystems regeneration (Silva et al., 2015). Lastly, the litterfall is a main source of material for nutrients cycling in tropical forests (Mateus et al., 2013; Londe et al., 2016). In fact, the nutrient cycling from decomposition of litter is one of the main ways of soil recovery in areas that have experienced anthropic exploration, mainly in tropical forests, where the nutrient cycling is fast and most soils have low fertility (Andrade et al., 2003).

The planting of seedlings in degraded areas may lead to increased litterfall production, as it had been reported in previous works in mature restoration areas (Machado et al., 2008; Miranda Neto et al., 2014). The production increases with density of planted seedlings (Alonso et al., 2015), therefore, the planting of grouped seedlings may provide the restoration of litterfall production faster than the plantation of seedlings in rows. However, there is an information gap about the litterfall production in early stages of restoration. Also, few studies had evaluated the effects of different planting systems on ecological processes restoration (Londe et al., 2016), especially in litterfall production.

Thereby, this study evaluated litterfall production in a two-years forest restoration area, in order to test differences between areas with and without seedling plantation of arboreous species; and between areas with plantation of seedlings in rows and in clusters. Two hypotheses were proposed: 1) the litterfall production is promoted by plantation of seedlings, being expected to find higher litter production and faster litter substitution in plantation than control plots and 2) the seedlings plantation system affects the production of litterfall, being expected that higger density in clusters will result in higger litterfall production and in faster substitution of the produced litter in plots with seedlings planted in clusters than in rows.

\section{MATERIALAND METHODS}

The study area is a forest restoration area at Petrobras's Monteiro Lobato Gas Treatment Station (UTGCA), on the right margin of Camburu River, in Caraguatatuba county, state of São Paulo (2339'15'S

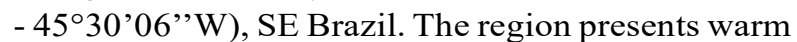
and humid tropical climate. The mean annual temperature in the study area was $23^{\circ} \mathrm{C}$, and the annual rainfall

Revista Árvore. 2017;41(3):e410319

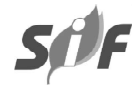


was 2870 mm between August 2013 and March 2014, with no clear dry season, but a higher precipitation period during January and March (data provided by UTGCA).

The original soils in the region are Spodosols and Entisols (Quartzipsamments), which are sandy, low fertility soils formed from the coastal sand deposits of the Quaternary (Restinga geomorphological formations) (Coelho et al., 2010). The soil of the study area differs from the original sandy soil of the Restinga formations due to the landslide that occurred in Caraguatatuba county in 1967, which resulted in the sliding of clayed materials from the Serra do Mar slope, with the consequent deposition of a $60 \mathrm{~cm}$ layer of clayed materials on the original sandy Restinga formation.

The phytophysiognomy to be restored was determined based on the geomorphological location along with a detailed floristic survey carried out on a nearby vegetation fragment, considered as a reference ecosystem. The physiognomy to be restored is the Transitional forest, which is characterized by High-Restinga-forest species with presence of Submontanerain-forest species, with higher nutritionally requirements. The upper layer of soil in Transitional forests is also composed of clayed materials from the slope deposited on sandy layers from the Restinga geomorphological formation (Joly et al., 2012).

Prior to the reforestation project, the area was a productive pasture for more than 40 years and vegetation was characterized by exotic grasses, mainly Brachiaria sp.. The planting of native seedlings was carried out between February and April 2012, with 15,693 seedlings of 54 tree species, including pioneer and non-pioneer species (Bertoncello et al., 2016). Seeds were previously collected in forest fragments in the SP Coastal-plain. The area was divided into 62 plots (about $10 \times 100 \mathrm{~m}^{2}$ size) intercalating plots with planting of seedlings in rows $(n=27)$, plots with seedlings in cluster $(n=27)$ and control plots without planting $(\mathrm{n}=8)$ (Figure 1$)$. In the row plots, each line was composed of seedlings of pioneer and non-pioneer species interspersed with a distance of 2 $\mathrm{m}$ between them (average density of 2,500 seedlings.ha ${ }^{-1}$ ). In the cluster plots, each cluster was composed by 13 seedlings ( 5 pioneer and 8 non-pioneer species) with distances of $30 \mathrm{~cm}$ between seedlings and $5 \mathrm{~m}$ between clusters (Figure 1). The distance between clusters was calculated to maintain the same density per plot in both planting systems $(2,500$ seedlings.ha- $\left.{ }^{-1}\right)$. In the control area no seedlings were planted, being the vegetal cover composed of exotic grasses. Grasses were controlled by cutting the aboveground part of the grasses every two months.
The litterfall was collected monthly between December 2012 and November 2014. Three collectors per plot $(71 \times 71 \mathrm{~cm}$ size $)$ were installed equidistant from the center of the plot, totaling 186 collectors. The collectors were made with a nylon mesh attached to a square support of PVC pipes. Each collector was installed $0.5 \mathrm{~m}$ from the ground with four supports of PVC pipes. The collected material was placed in paper bags. In the laboratory, the material was oven-dried at $70^{\circ} \mathrm{C}$ until constant weigh, and then weighted. For each plot, three types of sorting were carried out (one for each collector): 1: total litter dry weight; 2 : weight of litter fractions: leaves, thin twigs, thick twigs $(>5 \mathrm{~mm})$ and reproductive material and debris; And 3: separating the litterfall produced from grasses and litterfall from planting seddlings.

The annual litterfall production of each plot (W) was calculated by adding the total dry weight produced monthly on each plot for 12 consecutive months. In order to evaluate the replacement of the produced litter, it was elaborated the Substitution Index $\mathrm{SI}=\left(\mathrm{W}_{\mathrm{F}}-\mathrm{W}_{\mathrm{P}}\right) /$ $\mathrm{W}_{\text {TOTAL }}$, being $\mathrm{W}_{\text {TOTAL }}$ the annual litterfall production, $\mathrm{W}_{\mathrm{F}}$ the dry litterfall produced from seedlings and $\mathrm{W}_{\mathrm{P}}$ the dry litterfall produced from the grasses. Thereby $\mathrm{SI}=0$ indicates equal litterfall from seddlings and grasses; $-1 \leq$ IS $<0$ indicates higger litterfall from grasses than seddlings and $0-1 \leq \mathrm{IS}<1$ indicates higher litterfall from seedlings than grasses.

The effects of planting system (3 levels: rows, clusters and control) in litter production and replacement was tested using non-parametric Kruskal-Wallis (H) test, since data did not present normal distribution, even after being transformed. The significance level of 5\% was adopted. Differences in litter replacement were also tested between the two years of study. The tests were performed in InfoStat program (Di Rienzo et al., 2008).

\section{RESULTS}

Mean annual production in the restoration area (December 2012 to November 2014) was 210 g.m ${ }^{-2}$, which corresponds to $2.1 \mathrm{Mg} \cdot \mathrm{ha}^{-1}$. There were two peaks of litter production during the collection period, one in April 2013 and another beginning in April 2014 (Figure 2). In April 2013, a flood occurred in the area and the collectors were covered with mud and river debris, which originated part of the peak observed in that year, as evidenced by the high amount of debris in that month (data not 


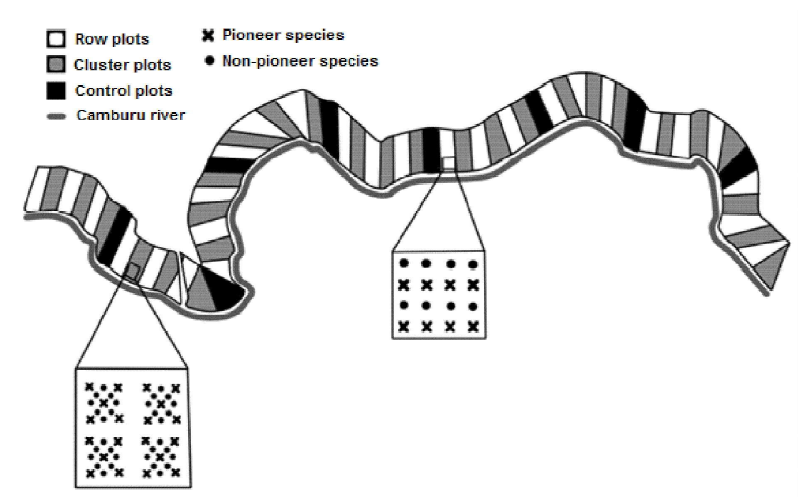

Figure 1 - Experimental design of the study area, located at the right margin of Camburu River, Caraguatatuba (SP). Disposition of plots with tree seedlings plantation in row (white rectangles, $\mathrm{n}=27$ ); plots with tree seedlings plantation in clusters (grey rectangles, $\mathrm{n}=27$ ); and control plots, without seedlings plantation (black rectangles, $\mathrm{n}=8$ ). Highlighted in the plots, the disposition of seedlings inside rows and clusters plantation systems.

Figura 1 - Desenho experimental da área de estudo, localizada à margem direita do Rio Camburu, Caraguatatuba (SP). A figura mostra a disposição de parcelas com plantio de mudas arbóreas em linha (rectângulos brancos, $n=27$ ); parcelas com plantio de mudas agrupadas (rectângulos cinzas, $n=27$ ); e parcelas controle sem plantio de mudas (retângulos pretos, $n=8)$. Em destaque nas parcelas, a disposição das mudas nos sistemas de plantio adensados e em linhas.

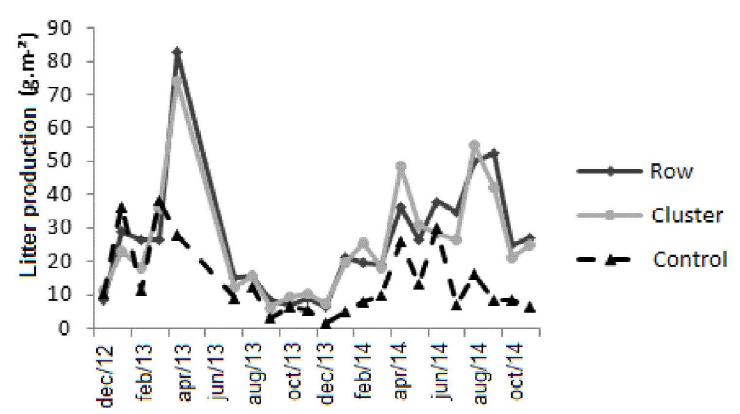

Figure 2 - Monthly litterfall production $\left(\mathrm{g} \cdot \mathrm{m}^{-2}\right)$ in plots with different types of tree seedlings plantation in a two years old restoration area in Caraguatatuba, SP $(n=27$ for row plantation, $n=27$ for cluster plantation and $n=8$ for control plots, without seedling plantation).

Figura 2-Produção mensal de serapilheira $\left(\right.$ g. $\left.m^{-2}\right)$ em parcelas com diferentes sistemas de plantio de mudas arbóreas em um reflorestamento de dois anos em Caraguatatuba, $S P(n=27$ para plantio em linhas, $n=27$ para plantio agrupado e $n=8$ para controle, sem plantio de mudas).

Revista Árvore. 2017;41(3):e410319 shown). It was observed an increase of litter production over time and also an increase of the proportion of litterfall from the planted seedlings. Even in the control areas, in which there was no planting, litterfall from the planted seedlings was observed.

In all plots, the most abundant litterfall fraction was leaves, varying from $72 \%$ to $81 \%$ (Figure 3 ). In plots with plantation of seedlings, the twigs production was higher than the material production, unlike in the control plots (Figure 3a). Apparently, the thick twigs were the fraction that most differed between plots, being higger in plantation than control plots (Figure 3a); and higger in row than cluster plots (Figure $3 b$ ).

The mean litterfall annual production was higger in plantation (254.91 g. $\left.\mathrm{m}^{-2}\right)$ than control plots $(120,99$ g. $\left.\mathrm{m}^{-2}\right)$, but there was no difference between row and cluster plots $(H=8.63 ; p=0.0134)$ (Table 1$)$.

The results indicated that the litterfall was replaced over time $(H=69.84, p<0.0001)$, with mean annual values of Substitution Index, SI, of -0.09 in 2013 and 0.12 in 2014 (values for seedlings plantation, both row and

a.
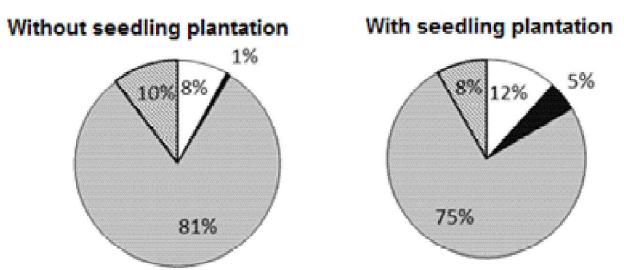

b.

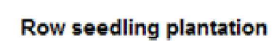

Cluster seedling plantation

$\square$ Thin twigs

- Thick twigs

घ Leaves

$\square \mathrm{R}+\mathrm{M}$
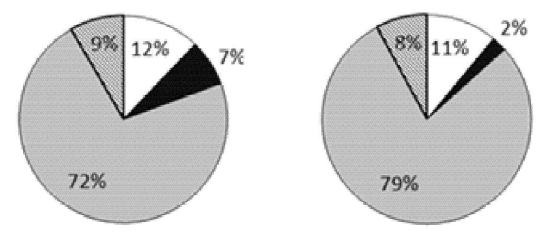

Figure 3 - Litterfall fractions produced annually in a two years old restoration area in Caraguatatuba, SP: a. in plots without seedling plantation and plots with seedling plantation; $\mathbf{b}$. in plots with row seedling plantation and plots with cluster seedling plantation. $\mathrm{R}+\mathrm{M}$ means reproductive and miscellaneous.

Figura 3 - Frações de serapilheira produzida anualmente em uma área em restauração de dois anos em Caraguatatuba, SP: a. nas parcelas sem plantio de mudas e nas parcelas com plantio de mudas; b. nas parcelas plantadas com mudas em linhas e nas parcelas plantadas com mudas agrupadas. $R+D$ significa reprodutivos e detritos. 
Table 1 - Annual litterfallproduction, substitution index and litter reproductive fraction as a function of the type of seedling plantation in a two years old restoration area in Caraguatatuba, SP ( $\mathrm{N}=$ number of plots). Different letters within columns indicate significant differences at $\alpha=0,05$ level of confidence.

Tabela 1 - Produção anual, índice de substituição e fração reprodutiva de serapilheira em função do sistema de plantio de mudas em um reflorestamento de dois anos em Caraguatatuba, $S P\left(N=n^{\circ}\right.$ de parcelas). Letras diferentes dentro da coluna indicam diferenças significativas ao nível de confiança de $\alpha=0,05$.

\begin{tabular}{lccccc}
\hline Plantation system & $\mathrm{N}$ & Annual production $\left(\mathrm{g} . \mathrm{m}^{-2}\right)$ & Substitution Index & Reproductive Fraction $(\%)$ \\
\hline Control & 8 & $120.99 \pm 54.35$ & $\mathrm{~A}$ & $-0.31 \pm 0.74 \mathrm{~A}$ & $5.76 \pm 7.82$ \\
Rows & 27 & $259.39 \pm 141.83 \mathrm{~B}$ & $0.09 \pm 0.80$ & $\mathrm{~B}$ & $11.42 \pm 13.50 \mathrm{~B}$ \\
Clusters & 27 & $250.59 \pm 147.51 \mathrm{~B}$ & $0.09 \pm 0.78$ & $\mathrm{~B}$ & $11.65 \pm 14.57 \mathrm{~B}$ \\
\hline
\end{tabular}

cluster plots). The litter substitution index, SI, was higher in the plantation than in the control plots, but it did not differ between plots planted in rows and clusters $(\mathrm{H}=27 ; \mathrm{p}<0.0001)$. The positive SI values in the plantation plots indicated a higher amount of litterfall produced by the planted seedlings than by the pre-existing pasture vegetation (grasses) in the area, while the negative SI values in the control plots indicated a greater amount of litterfall from grasses than planted seedlings (Table 1).

The percentage of reproductive material in the litterfall was higher in planted than in control plots, but there were no differences between rows and cluster plots $(\mathrm{H}=31.07, \mathrm{p}<0.0001)$.

\section{DISCUSSION}

\subsection{Litterfall produced in early stages of reforestation}

The values of litterfall annual production observed were lower than those reported in Highrestinga forests in late successional stages. In similar climatic conditions, the high-restinga in Ilha do Mel (PR) had an annual litterfall production of 501 g.m${ }^{2}$ (Pires et al., 2006), and of 390 g. $\mathrm{m}^{-2}$ in Ilha do Cardoso (SP) (Moraes et al., 1999). In ombrophylous rain forest of the Atlantic Forest biome, litterfall production appears to be even larger, with annual production of 347 g. $\mathrm{m}^{-2}$ in dense ombrophylous forest in Ibiúna (SP) (Ferreira and Uchiyama, 2015) and values of 706 to 809 g.m $\mathrm{m}^{-2}$ in submontane forests in Paraná (Bianchin et al., 2016).

Litterfall production can be affected by the vegetation successional stage. In fragments of dense ombrophilous rain forest in the state of São Paulo, Vendrami et al. (2012) founded higher litterfall production in the early stages of succession (25 years) than in fragments of late successional stages (over 65 years), which may have occurred because in the early stages there is a greater proportion of pioneer species. On the other hand, there were no differences in annual litter production in submontane rain forests ranging from 50 to 80 years in Paraná, probably because all areas presented late successional stages (Bianchin et al., 2016). In contrast, litter accumulation may also be related to the basal area, so that the larger the basal area of the trees in the restoration area, the greater the amount of produced litter (Miranda Neto et al., 2014). Thus, the amount of litter observed in the present study, which is lower than this reported in mature forests, may be related to the basal area of the seedlings after two years of planting, which is much smaller than that of adult trees. The results of Correia et al. (2016) corroborate, reporting lower litter stocks in restored areas of 23 years than in the nearby board mature forest (Correia et al., 2016). In addition, they found a positive correlation between the Plant Index Area (the area occupied by the canopy elements, such as leaves, branches, flowers and fruits, in relation to the soil area) and the accumulation of litterfall, so that the more closed and structured the canopy, the greater the accumulation of litter on the soil. Therefore, the canopy still opened in the study area is another factor that may have contribute to the low production of litter.

The distribution of litterfall throughout the year showed a peak of production after the rainy season (April to October), which had been also reported in submontane rainforest (Bianchin et al., 2016), as opposed to that found in previous studies in restinga, where peak production occurs shortly after the dry period (Moraes et al., 1999; Pires et al., 2006). This difference between results can be related to the soil water retention, which should be higher in clayed soils of the slope than in the very sandy soils typical of the restingas (Joly et al., 2012). Some previous studies have also described two peaks of litterfall production throughout 
the year, which are strongerly marked in areas of reforestation with dense spacing or in secondary forests with well-structured canopy (Alonso et al., 2015; Bianchin et al., 2016). In any case, the observed results point to the importance of the microclimate as a determinant factor of litterfall seasonality.

The leaves were the most abundant fraction of litterfall, as generally indicated in litterfall quantitative studies. In Ilha do Mel, $75 \%$ of leaves, $18 \%$ of branches and $7 \%$ of reproductive and miscellaneous material were found (Pires et al., 2006). Meanwhile, Machado et al. (2008) founded $70 \%$ to $86 \%$ of leaves, $10 \%$ to $20 \%$ of branches, $4 \%$ to $9 \%$ of reproductive material and $0.5 \%$ to $11 \%$ of miscellaneous in a reforested area of decidual seasonal tropical forest in Rio de Janeiro. In our control areas, the fractions that occurred in greater quantity were also the leaves, followed by the reproductive material and the branches, in a similar way to that described by Machado et al. (2008) in a pasture in Conceição de Macabu (RJ) of humid tropical climate. The presence of leaves of tree seedlings in the control plots may be related to their low weight, which facilitates their dispersion by the wind, which does not occur with heavier fractions such as the branches.

A greater number of branches was observed in the litterfall of the plantation areas as opposed to the control areas, which can be explained by the presence of tree seedlings. There was also a greater proportion of branches in the planting areas of row seedlings than in the cluster ones, probably because the higher density inhibits the exchange activity and the thickening of the branches. On the other hand, Alonso et al. (2015) found a higher proportion of twigs in cluster plantation ( $22 \%$ versus $11 \%$ in conventional spacing), which the authors related to the higher debris production under shade conditions. It is worth to remember that at the study time, the area of study was two-years old and the canopy had not yet closed. Mota and Torezan (2013) found increases of necromass and woody fractions of litterfall with age in areas of restoration of 4, 6 and 8 years in the Atlantic Forest biome in Paraná. However, there were no differences between the fractions when comparing the first two years of planting in the present study.

\subsection{Effects of reforestation}

In general, differences were found in the litterfall produced between areas with and without planting of seedlings, but no differences were found as a function of the planting system. Annual litterfall production and litter substitution index were higher in planting areas than in control ones, but it did not differ between areas planted with seedlings in rows and clusters.

The observed differences between plantation and control areas indicate that litterfall production is being restored in areas where seedlings were planted. In the control areas, values close to those reported for pasture areas were observed (Machado et al., 2008). Machado et al. (2008) found $62 \mathrm{~g} . \mathrm{m}^{-2}$ of litter, whereas in this study the value obtained for the control areas was $120.99 \mathrm{~g} . \mathrm{m}^{-2}$. In addition, litterfall from the planted seedlings was found in the control areas, which indicates dispersion of the material produced by the seedlings outside the planting plots, probably carried by the wind. It is not possible to know whether this dispersion will be enough to induce litterfall restoration in the medium and long term in control areas.

Another observed effect of planting of seedlings was the replacement of the litterfall produced over time, so that in the planting areas, the litterfall produced from the tree seedlings was higher than the litterfall from grasses. This difference was already expected, since the presence of the pioneer tree species, which have a rapid growth, leads to the formation of shade, which inhibits grass growth (Rodrigues et al., 2009).

In previous studies carried out in a reforestation site in Seropédica (RJ) with different distances between seedlings, there was higher litterfall production and higher nutrient content in more densely row plantations (Alonso et al., 2015; Villa et al., 2016). On the other hand, restoration areas of 15 years in the country side of the state of São Paulo had similar values for litter accumulation in plantations with different spacings and proportions of pioneer and non-pioneer species (Soares et al., 2016), corroborating with the results observed here. In the present work, the planting in densified clusters obtained the same production of litterfall as the planting in rows. A possible explanation is the fact that the densified clusters had a lower proportion of pioneer species (8NP: $5 \mathrm{P}$ ) than the row planting system (1NP: 1P). Pioneer species produce higher amounts of litter since they have greater investment in growth and few conservative strategies(BenvenutiFerreira et al. 2009). Thus, there may have been a compensation between the higher litterfall production in clustered plantations and the higher production by pioneer species in rows, resulting in similar litterfall production for both planting systems.

Revista Árvore. 2017;41(3):e410319 
Based on the results, the planting of seedlings in row or clusters is recommended to recover the nutrient cycling in the initial stages of restoration, since both were equally effective in restoring the litterfall production process. However, the planting of cluster seedlings have higher costs, as it makes it difficult to mechanize the implantation, management and monitoring of the area. On the other hand, a recent work carried out in the same study area showed lower mortality of non-pioneer species in cluster than row planting system (Bertoncello et al., 2016), which suggests that the effects of planting techniques differ among ecological process, so that the recommendation of restoration techniques should not be based on a single ecological process. Also, the combined use of different planting techniques can maximize the recovery of several ecological processes in the restoration of degraded areas.

\section{CONCLUSION}

The plantation of seedlings facilitates the recovery of litterfall production, with a gradual replacement of the material produced from the initial stages of the restoration.

The litterfall production did not differ between the two compared planting systems in the present study, seedlings planted in rows or in densified clusters were equally efficient to recover litterfall in a two-year restoration area of transition forest between high-resting $a$ and submontane rain forest.

These conclusions support the use of planting of seedlings as a restoration technique that promotes the recovery of nutrient cycling in degraded areas, regardless of the arrangement of seedlings in rows or clusters.

\section{ACKNOWLEDGMENT}

The present study was developed in scope of the project Ecology and Restoration of Ecosystems of the Coastal Plain of the North Coast of São Paulo. We thank Petrobras for the financing and to Conselho Nacional de Desenvolvimento Científico e Tecnológico (CNPq) for the scholarship from PIBIC Program 2015/ 16. We also thank LabTrop USP for the coordination of the project, specially Marcelo Pansonato, responsible for field work and Juliana Vendrami for text suggestions.

\section{REFERENCES}

Alonso JM, Leles SS, Ferreira LN, Oliveira SA. Aporte de serapilheira em plantio de recomposição florestal em diferentes espaçamentos. Ciência Florestal. 2015;25:jan/mar.
Andrade AG, Tavares SRL, Coutinho HLC. Contribuição da serapilheira para recuperação de áreas degradadas e para manutenção da sustentabilidade de sistemas agroecológicos. Informe Agropecuário. 2003;24(220):55-63.

Benvenuti-Ferreira G, Coelho GC, Schirmer J, Lucchese OA. Dendometria e produção de serapilheira de espécies arbóreas neotropicais pioneiras e secundárias inicias. Biota Neotropica. 2009;9:65-71.

Bertoncello R, Oliveira AA, Holl K, Pansonato MP, Martini AMZ. Cluster planting facilitates survival but not growth in early development of restored tropical forest. Basic and Applied Ecology. 2016;17(6):489-96.

Bianchin JE, Marques R, Britez RM, Capretz RL. Deposição de Fitomassa em Formações Secundárias na Floresta Atlântica do Paraná. Floresta e Ambiente. 2016;23(4):524-33.

Coelho MR, Martins M, Vidal-Torrado P, Souza CRG, Perez XLO, Vázquez FM. Relação solorelevo-substrato geológico nas restingas da planície costeira do estado de São Paulo. Revista Brasileira de Ciência do Solo. 2010;34(3):833-46.

Correia GGS, Martins SV, Miranda Neto A, Silva KA. Estoque de serapilheira em floresta em restauração e em Floresta Atlântica de Tabuleiro no Sudeste brasileiro. Revista Árvore.2016;40:13-20.

Di Rienzo JA, Balzarib MG, Robledo CW, Casanoves F, Balzarini MG, Gonzalez LA. et al. InfoStat: manual do usuário. Argentina: Brujas; 2008.

Ferreira ML, Uchiyama EA. Avaliação da serapilheira num fragmento de floresta secundária tropical, Ibiúna, sudeste do Brasil. Revista Árvore. 2015;39(5):791-9.

Joly CA, Assis MA, Bernacci LC, Tamashiro JY, Campos MCR, Gomes JAMA et al. Florística e fitossociologia em parcelas permanentes da Mata Atlântica do sudeste do Brasil ao longo de um gradiente altitudinal. Biota Neotropica. 2012;12:125-45.

Londe V, Caldas de Sousa H, Kozovits AR. Litterfall as an indicator of productivity and

Revista Árvore. 2017;41(3):e410319 
recovery of ecological functions in a rehabilitated riparian forest at Das Velhas River, southeast Brazil. Tropical Ecology. 2016; 57(2): 355-60.

Machado MR, Rodrigues FCMP, Pereira MG. Produção de serapilheira como bioindicador de recuperação em plantio adensado de revegetação. Sociedade de Investigações Florestais, 2008;32:143-51.

Mateus FA, Miranda CC, Valcarcel R, Figueiredo HA. Estoque e capacidade de retenção hídrica da serapilheira acumulada na restauração florestal de áreas perturbadas na Mata Atlântica. Floresta e Ambiente. 2013;20(3):336-43.

Millennium Ecosystem Assessment. Ecosystems and Human Well-being: Synthesis. Washington, DC: Island Press; 2005.

Miranda Neto A, Martins SV, Silva KA, Gleriani JM. Banco de sementes do solo e serapilheira acumulada em floresta restaurada. Revista Árvore. 2014;38:609-20.

Moraes RM, Delitti WBC, Struffaldi de Vuono Y. Litterfall and litter nutrient content in two Brazilian Tropical Forests. Revista Brasileira de Botânica. 1999;22:9-16.

Mota MC, Torezan JMD. Necromassa em reflorestamentos com espécies nativas da Mata Atlântica com 4, 6 e 8 anos de implantação. Hoehnea.2013;40:499-505.

Pires LA, Britez RM, Martel G, Pagano S. Produção, acúmulo e decomposição da serapilheira em uma restinga da Ilha do Mel, Paranaguá, PR, Brasil. Acta Botânica Brasilica. 2006;10:173-84.
Rocha CFD, Bergallo HG, van Sluys M, Alves MAS, Jamel CE. The remnants of restinga habitats in the brazilian Atlantic Forest of Rio de Janeiro state, Brazil: Habitat loss and risk of disappearance. Brazilian Journal of Biology. 2007;67:263-73.

Rodrigues RR, Brancalion HS, Isernhagen B. Pacto pela restauração da mata atlântica: referencial dos conceitos e ações de restauração florestal. São Paulo: Instituto BioAtlântica; 2009. $264 p$.

Ruiz-Jaen MC, Aide TM. Restoration success: how is it being measured? Restoration Ecology. 2005;13(3):569-77.

Silva KA, Martins SV, Miranda Neto A, Campos WA. Semeadura direta com transposição de serapilheira como metodologia de restauração ecológica. Revista Árvore. 2015;39:811-20

Soares AAV, Botelho SA, Davide AC, Faria JMR. Influência da composição de grupos ecológicos, espaçamento e arranjo de plantio na recuperação de matas ciliares em margem de reservatório. Ciência Florestal. 2016;26(4):1107-18.

Vendrami JL, Jurinitz CF, Castanho CT, Lorenzo L, Oliveira AA. Litterfall and leaf decomposition in forest fragments under different successional phases on the Atlantic Plateau of the state of São Paulo, Brazil. Biota Neotrópica. 2012;12:134-41.

Villa EB, Pereira MG, Alonso JM, Beutler SJ, Leles SS. Aporte de serapilheira e nutrientes em área de restauração florestal com diferentes espaçamentos de plantio. Floresta e Ambiente. 2016;23(1): jan/ mar.

Revista Árvore. 2017;41(3):e410319 